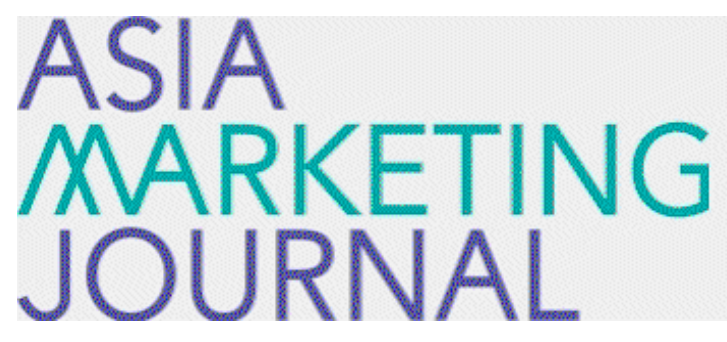

ASIA MARKETING JOURNAL

Volume 15 | Issue 3

Article 4

10-30-2013

\title{
Informative Role of Marketing Activity in Financial Market
}

Kyung Oh Yun

Follow this and additional works at: https://amj.kma.re.kr/journal

Part of the Marketing Commons

\section{Recommended Citation}

Yun, Kyung Oh (2013) "Informative Role of Marketing Activity in Financial Market," Asia Marketing Journal: Vol. 15 : Iss. 3 , Article 4.

Available at: https://doi.org/10.53728/2765-6500.1558

This Article is brought to you for free and open access by Asia Marketing Journal. It has been accepted for inclusion in Asia Marketing Journal by an authorized editor of Asia Marketing Journal. 


\title{
Informative Role of Marketing Activity in Financial Market: Evidence from Analysts' Forecast Dispersion*
}

\author{
Yun Kyung $\mathrm{Oh}^{* *}$
}

As advertising and promotions are categorized as operating expenses, managers tend to reduce marketing budget to improve their short term profitability. Gauging the value and accountability of marketing spending is therefore considered as a major research priority in marketing. To respond this call, recent studies have documented that financial market reacts positively to a firm's marketing activity or marketing related outcomes such as brand equity and customer satisfaction. However, prior studies focus on the relation of marketing variable and financial market variables. This study suggests a channel about how marketing activity increases firm valuation. Specifically, we propose that a firm's marketing activity increases the level of the firm's product market information and thereby the dispersion in financial analysts' earnings forecasts decreases. With less uncertainty about the firm's future prospect, the firm's managers and shareholders have less information asymmetry, which reduces the firm's cost of capital and thereby increases the valuation of the firm. To our knowledge, this is the first paper to examine how informational benefits can mediate the effect of marketing activity on firm value.

To test whether marketing activity contributes to increase in firm value by mitigating information asymmetry, this study employs a longitudinal data which contains 12,824 firm-year observations with 2,337 distinct firms from 1981 to 2006. Firm value is measured by Tobin's Q and one-year-ahead buy-and-hold abnormal return (BHAR). Following prior literature, dispersion in analysts' earnings forecasts is used as a proxy for the information gap between management and shareholders. For model specification, to identify mediating effect, the three-step regression approach is adopted. All models are estimated using Markov chain Monte Carlo (MCMC) methods to test the statistical significance of the mediating effect. The analysis shows that marketing intensity has a significant negative relationship with dispersion in analysts' earnings forecasts. After including the mediator variable about analyst dispersion, the effect of marketing intensity on firm value drops from 1.199 ( $p$ $<.01)$ to 1.130 ( $\mathrm{p}<.01)$ in Tobin's Q model and the same effect drops from .192 ( $<<.01$ ) to .188 $(\mathrm{p}<.01)$ in BHAR model. The results suggest that analysts' forecast dispersion partially accounts for the positive effect of marketing on firm valuation. Additionally, the same analysis was conducted

\footnotetext{
* This research project was supported by the Dongduk Women's University grant.

** Assistant Professor of Marketing Dongduk Women's University(ykohl@dongduk.ac.kr)
} 
with an alternative dependent variable (forecast accuracy) and a marketing metric (advertising intensity). The analysis supports the robustness of the main results.

In sum, the results provide empirical evidence that marketing activity can increase shareholder value by mitigating problem of information asymmetry in the capital market. The findings have important implications for managers. First, managers should be cognizant of the role of marketing activity in providing information to the financial market as well as to the consumer market. Thus, managers should take into account investors' reaction when they design marketing communication messages for reducing the cost of capital. Second, this study shows a channel on how marketing creates shareholder value and highlights the accountability of marketing. In addition to the direct impact of marketing on firm value, an indirect channel by reducing information asymmetry should be considered. Potentially, marketing managers can justify their spending from the perspective of increasing long-term shareholder value.

Key words: marketing-finance interface, marketing metrics, firm value, information asymmetry, analysts forecast dispersion

\section{Introduction}

Managers and investors increasingly pay more attention to the impact of marketing on firm valuation (Anderson et al. 2004). In many cases, managers face difficulty in justifying their marketing budget due to lack of accountability. With its research priority (Rust et al. 2004), recent studies have documented whether financial market reacts positively to a firm's marketing activity (Erickson and Jacobson 1992) or marketing related outcomes such as brand equity (Mizik and Jacobson 2008, 2009) and customer satisfaction (Fornell et al. 2006, Yi et al. 2008).

A few marketing studies have examined the intermediate variables to explain the underlying process on how marketing creates shareholder value. For example, Joshi and Hanssens (2010) gauge the direct and the indirect effect (measured by total effect minus direct effect) of advertising spending on firm value through boosting sales and profits.

To extend prior studies, this study proposes and tests an alternative indirect channel to explain how marketing affects firm value. That is, through marketing activities, a firm can reduce information asymmetry between managers and shareholders and therefore reduce a cost of capital. As a communication channel, a firm's marketing activity provides product information not only to target customers but also to current and potential investors. Although 
a firm regularly releases earnings-related information directly through IR (investor relationship) news, investors could also learn the major features of the firm's products from marketing activities such as advertising, sales force, and promotional activity. Thus, as a secondary information source, a firm's marketing could help investors have more accurate financial outlook for the firm. In this way, the spill-over effect of marketing activity enables a firm to mitigate information asymmetry. Low information asymmetry is beneficial to firm value by reducing the cost of capital.

In this study, we test whether or not marketing contributes to increasing firm value by mitigating information asymmetry. Specifically, we examine the mediating role of analysts earnings forecast dispersion in the relationship between marketing intensity and firm value (measured by Tobin's Q and buy-and-hold abnormal return). Dispersion in analysts' earnings forecasts is often used as a proxy for the information gap between management and shareholders (Karamanou and Vafeas 2005: Lang and Lundholm 1996). We find that marketing intensity is negatively associated with the divergence of analysts opinions. Furthermore, marketing activity increases firm value by lowering analysts' forecast dispersion.

Different from prior studies that infer the indirect effects of advertising, we test the statistical significance by using a Bayesian mediation approach. To our knowledge, this is the first paper to examine how informational benefits (confirmed by lower dispersion in analysts earnings forecasts) can mediate the relationship between marketing and firm valuation. In the next section, we outline the background theory and related literature. Then we develop hypotheses regarding how marketing influences analysts' forecast dispersion and, subsequently, firm value. Next, we describe our data, specify our empirical model and report analysis results from the model. Finally, we conclude, suggest managerial implications and discuss future research questions.

\section{Theory and Hypotheses}

\section{Informative Role of Marketing in Financial} Market. Prior studies document the informative role of advertising in product market (Nelson 1974: Milgrom and Roberts 1986). For example, Nelson (1974) argues that advertising for search goods carries direct information, while advertising for experience goods carries indirect information about the brand. Likewise, a firm's marketing activity can help outside investors (shareholders) become aware of a new product and learn about the unique product features. For example, financial analysts, who pay great attention to the public news for the firm they follow, are likely to reflect the product market information into their earnings forecasts. With 
the increased level of information, analysts' earnings forecasts are more likely to be accurate (i.e., a more accurate prospect of the level, timing, and volatility of the firm's future cash flows).

Barry and Brown (1985) model a setting where disagreement increases when there is more private information than public one regarding a firm. Empirically, dispersion in analysts earnings forecasts is often used as a proxy for the information gap between managers and shareholders (e.g., Karamanou and Vafeas 2005: Lang and Lundholm 1996). Since a firm's marketing activity delivers product market information to shareholders, an increase in marketing activities could reduce the information gap between managers and shareholders.

Taken together, all else being equal, we expect analysts to show less divergence in opinions for a firm's future earnings when the firm has higher marketing intensity.

\section{$H_{1}$ : Dispersion in analysts' earnings forecasts} decreases as a firm's marketing intensity increases.

That is, $\mathrm{H}_{1}$ predicts that a firm's higher marketing spending will lower dispersion in analysts' earnings forecasts for the following year.

The Effect of Information Asymmetry on Firm Value. Under the semi-strong form of financial market efficiency (Fama 1970), a firm's insiders (managers) have more information about the firm's future prospects than outside investors (shareholders), which leads to the information asymmetry between the two of them. The information asymmetry problem could increase the firm's cost of external financing (Myers and Majuf 1984). In the model of Merton (1987), investors demand premium for bearing information risk when there is an information asymmetry between managers and shareholders. Therefore, managers have an incentive to increase corporate disclosure because the value-relevant information helps to reduce information asymmetry and thereby lower the firm's cost of capital (Barry and Brown 1985: Lang and Lundholm 1996). As such, when marketing activities convey product market information to outside investors, the marketing action could lower cost of capital by reducing information asymmetry between managers and shareholders.

\section{Marketing Activity, Analyst's Forecast} Dispersion, and Firm Value. In $\mathrm{H}_{1}$, we test whether investors' opinions about a firm's future outlook converge as they face greater marketing activity by the firm. Does this imply that a firm's financial performance reflects the benefits of marketing activity through diminished information asymmetry? Related prior studies have two paths. First, the finance literature suggests that a firm with high dispersion in analysts' forecasts typically yields 
negative stock returns (Diether, Malloy, and Scherbina 2002: Fang and Peress 2009). Second, research on the effect of marketing activity on firm value has shown that a firm's marketing related activities (e.g., advertising and promotion) and marketing outcomes (e.g.. customer satisfaction and brand equity) help increase and stabilize cash flows (e.g.. Srinivasan and Hanssens 2009: Joshi and Hanssens 2010: Mizik and Jacobson 2003, 2008, and 2009).

Based on $\mathrm{H}_{1}$ and results from existing literature, we posit a 'chain of effects' starting from marketing to analysts' forecast dispersion, and ultimately to firm value. How marketing influences firm valuation through a channel (i.e., an indirect effect of marketing on firm value) is rarely examined in the marketing literature although examining the chain of effects enhances our understanding on how marketing affects firm value. One exception is Joshi and Hanssens (2010), where they study how marketing affects firm value through sales. In this paper, we suggest an alternative indirect channel, analysts forecast dispersion. We employ Tobin's Q (Mittal et al. 2005: Rao, Agarwal, and Dahlhoff 2004) and buy-and-hold abnormal returns (BHAR) (Jacobson and Mizik 2009) as a measure of firm value.

Taken together, we propose that low dispersion in analysts forecasts can partially mediate the positive impact of marketing on a firm's financial performance. We exclude the possibility that analysts forecast dispersion is a full mediator because sales and profits are known as significant indirect channels in the value relevance of marketing (e.g.. Joshi and Hanssens 2010). This leads to our second hypothesis:

\section{$\mathrm{H}_{2}$ : The impact of marketing intensity on firm value(Tobin's $Q$. BHAR) will be partially mediated by analysts' forecast dispersion.}

\section{〈Figure 1〉 Conceptual Framework}

The effect of marketing intensity on firm value considering the mediating effect of analysts forecast dispersion.

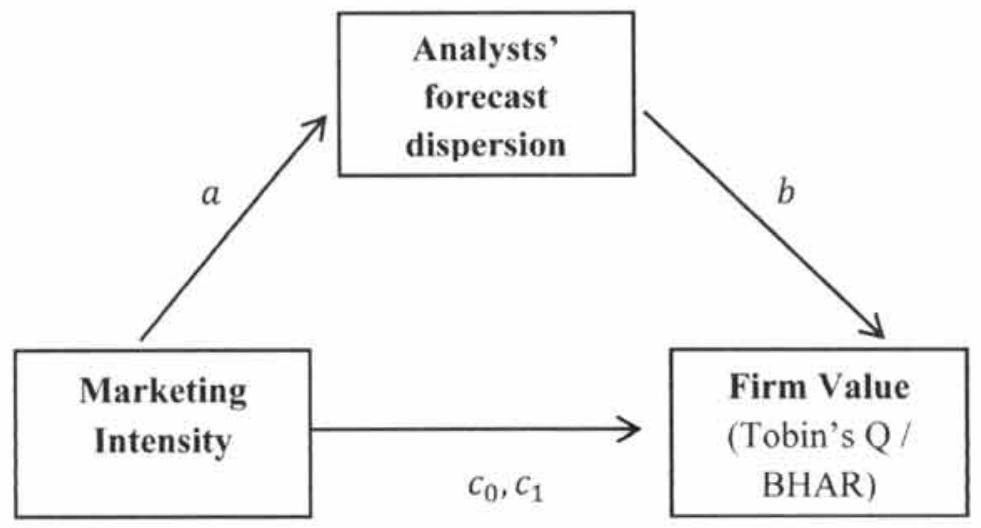


$\mathrm{H}_{2}$ predicts that firm valuation would increase as marketing activity alleviates information asymmetry in the stock market.

\section{Data}

We obtain the sample of analysts' forecast data for earnings per share (EPS) from the Institutional Brokers Estimate System (I/B/ E/S) Summary History file. I/B/E/S collects mean and standard deviation values of forecasts for individual firms earnings for current and subsequent fiscal year from outstanding analysts every month. Using I/B/E/S Summary History file, we select one-year-ahead forecasts of December from 1981 to 2006. ${ }^{1)}$ To measure divergence of opinion, we require that each firm has at least two following analysts when the forecast summary was reported. For those selected firms, we identify the firms that also have annual accounting data and monthly stock returns available from COMPUSTAT and CRSP (the Center for Research in Security Prices) respectively. As we depict in Figure 2 , we match explanatory variables from COMPUSTAT and CRSP (e.g., volatility) in year $t$ with dispersion in analysts' one-yearahead forecasts made at the end of year $t$. Firm valuation measures such as Tobin's Q and annualized stock returns are calculated in year $t+1$. By doing so, we enable analysts' forecasts to reflect marketing activity occurred during the same year. Furthermore, we can examine whether both marketing activity and analysts' forecast dispersion can explain financial performance in the subsequent year. In addition, following conventional finance literature (e.g., Thomas 2002), we exclude the regulated industries such as utilities (SIC code: 4900-4999) and financial services (SIC code: 6000-6999) which might have different leverage structure. After screening, our final sample contains 12,824 firm-year observations with 2,337 distinct firms.

Analysts' Forecast Dispersion. To reflect the impact of marketing actions on analysts' expectations for a firm's future financial outcome, we select one-year-ahead analysts' forecasts for annual earnings per share (EPS) made at the end of year $t$. With selected data from I/B/E/S, analysts forecast dispersion for firm $i$ in year $t$ is measured with the standard deviation of analysts' forecasts scaled by the absolute mean value of the forecasts. As discussed earlier, a larger dispersion in analysts' forecasts corresponds to severe asymmetric information problem in financial market (e.g., Diether, Malloy, and Scherbina 2002).

\footnotetext{
1) To ensure a consistent time framework when merging three databases ( $\mathrm{I} / \mathrm{B} / \mathrm{E} / \mathrm{S}$. COMPUSTAT, CRSP), we restrict the sample to include the firms having December as fiscal year ending month.
} 
〈Figure 2〉 Time Line of Measurements in Analysis

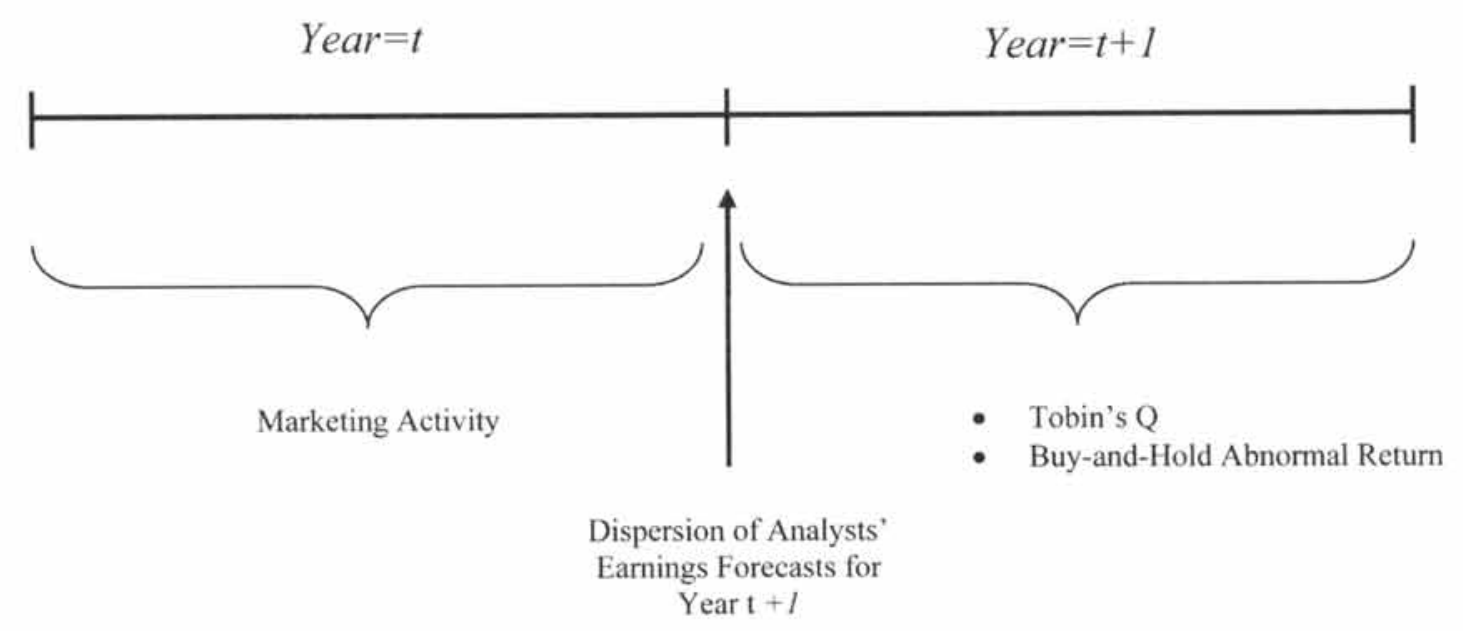

Marketing Intensity. Recent empirical studies in marketing (Mizik and Jacobson 2007: Luo 2008) employ marketing intensity as a proxy for the extent of marketing expenditure of a firm. Following the prior literature, we derive marketing intensity of firm $\mathrm{i}$ in year $\mathrm{t}$ using SG\&A expense (Selling, General and Administrative expenditure) minus $R \& D$ expense scaled by total asset in the same year.

$$
\text { Marketing Intensity } y_{i t}=\frac{\text { SG\&A Expense } \text { it }_{\text {-RLD Expense }} \text { it }}{\text { Total Asse }_{i t}}
$$

Marketing intensity measure is considered to cover marketing related expenditure such as advertising, R\&D, sales force compensation, promotional expense and other related expense. Further, we isolate the portion of $R \& D$ expense from SG\&A expense to better capture marketing related expense following Mizik and Jacobson (2007, p.367). SG\&A-R\&D measure has advantages over using single advertising measure for two reasons. First, SG\&A-R\&D includes expenses to manage marketing communication channels as well as advertising expense. Therefore it enables us to better assess the effect of marketing activities which can potentially influence investors' decision. Second, many firms do not report advertising spending while they report SG\&A or R\&D expenses regularly. This tendency results in a great deal of missing information for advertising in COMPUSTAT. Hence, the sample size for analysis is reduced drastically (only 4,975 firm-year observations are left). Consistent with prior research, we adopt marketing intensity to measure how much a firm spends marketing related expenses in year $t$ relative to its firm size. Nonetheless, we also test with advertising intensity (=advertising expense/total asset) as an alternative measure of marketing intensity and find that main results do not 
change materially.

Tobin's Q. Tobin's $\mathrm{Q}$ is widely used as a measure of a firm's long-term financial performance (Mittal et al. 2005: Rao et al. 2004) and defined as the ratio of a firm's market value of assets to the replacement costs of its assets. Following conventional finance literature, we approximate the replacement costs of assets by the book value of total assets. The market value of assets is approximated by the market value of common equity plus the market value of debt. The market value of debt is assumed to be equal to the book value of debt. Thus, when a firm creates higher market value relative to its replacement costs, we can interpret that the firm's valuation in the stock market is higher, reflecting higher future growth opportunity.

Buy-and-Hold Abnormal Returns. We compute 1-year buy-and-hold abnormal returns as a proxy for a firm's stock return performance in year $t+1$. The 1-year buy-and-hold abnormal returns reflect abnormal returns which an investor expects to earn by holding a stock for one year (Lyon, Barber and Tsai 1999: Jacobson and Mizik 2009). They are abnormal returns in that we control for the market risk using the capital asset pricing model (CAPM). The regression form is specified as $R_{i \tau}-R_{f \tau}=a+\beta$
$\left(R_{m \tau}-R_{f \tau}\right)+\varepsilon_{i \tau}$, where $R_{i \tau}$ denotes the monthly raw return for firm $\mathrm{i}$ in month $\tau, R_{f t}$ is 1 -month $\mathrm{T}$-bill rate in month $\tau$, and $R_{m \tau}$ is the value-weighted return of all stocks in CRSP during the same period. By running time series regression for each firm, parameter coefficients are obtained. Subsequently we can compute the expected return of firm $i$ in month $\tau$ as follows: $E\left(R_{i \tau}\right)=R_{f \tau}+\hat{\beta}_{i}\left(R_{m \tau}-\right.$ $\left.R_{i \tau}\right)$. Then, monthly raw returns and monthly expected returns are annualized for each firm by compounding the monthly returns. Finally, 1-year buy-and-hold abnormal return for firm $i$ in year $t+1$ is computed from the difference between the annualized raw return and the annualized expected return, $\Pi_{\tau=1}^{12}\left(1+R_{i \tau}\right)-$ $\Pi_{\tau=1}^{12}\left(1+E\left(R_{i \tau}\right)\right)$.

\subsection{Control Variables for Analysts' Forecast Dispersion}

To investigate the net effect of marketing intensity on analysts forecast dispersion, we control for several factors such as (1) R\&D Intensity, (2) Volatility, (3) Leverage, (4) Firm Size, and (5) Analyst Coverage. Thomas (2002) reports that these five factors have impacts on the extent of information asymmetry in capital market.

2) We also tested with alternative measures such as SG\&A intensity (=SG\&A expense / total asset) and found that main results do not change materially. 
$R \& D$ Intensity. A firm usually increases its $R \& D$ expenditure seeking future growth opportunities. With limited information available, it is difficult for analysts to evaluate whether $R \& D$ investment leads to a success or a failure in the future. Thus, we expect that greater $\mathrm{R} \& \mathrm{D}$ expenditure is associated with greater dispersion due to increased uncertainty. We measure $R \& D$ intensity using the ratio of R\&D expense to total asset.

Volatility. Stock return volatility is significantly associated with information asymmetry (Alford and Berger 1999: Thomas 2002). More precisely, high stock return volatility implies that stock returns fluctuate severely. Hence, volatility is expected to increase dispersion in analysts' forecasts. We control for the stock return volatility, which is measured by the standard deviation of daily raw returns for firm $i$ in year $t$ from CRSP.

Leverage. The ratio of total liability to total asset is used to measure a firm's leverage. High level of leverage might worsen a firm's financial status because a firm with high interest payments may face a high default probability. Hence, higher leverage is expected to increase uncertainty on a firm's financial status, thereby causing more disagreement in analysts' forecasts.

Firm Size. Large size firms are more likely to be public-owned and to have more information disseminated compared to small size firms. Thus, firm size should be negatively associated with dispersion in forecasts (Atiase 1985). In this study, we use the logarithm of the book value of total assets as a measure of firm size.

Analyst coverage. Analyst coverage is the number of analysts who follow a firm in year t. Prior study shows that larger analyst coverage represents more information available about the firm and is related to higher disclosure score (Lang and Lundholm 1996). As more analysts gauge a firm, uncertain information on a firm is more likely to be filtered. Thus, analyst coverage is expected to lower dispersion in forecasts.

\subsection{Control Variables for Tobin's Q}

Following existing empirical literature (Rao et al. 2004), we include control variables to explain Tobin's Q so that we can better capture the net impact of both marketing intensity and analysts' forecast dispersion on firm valuation. The factors are: (1) R\&D Intensity, (2) Leverage, (3) Operation Margin, (4) Growth Rate of Sales, and (5) Industry Concentration, which appear to influence firm valuation.

$R \& D$ Intensity. As $R \& D$ expenditure aims to increase future growth opportunities, it is likely to increase a firm's market valuation (Chauvin and Hirschey 1993: Rao et al. 2004). Thus, we 
expect a positive effect of $R \& D$ on Tobin's $Q$.

Leverage. Smith and Watts (1992) find that low leverage is associated with high growth opportunities. Recently, Rao et al. (2004) provide empirical evidence of the negative relationship between leverage and Tobin's Q. Hence, we expect that leverage is negatively related to firm valuation.

Operation Margin. We calculate operation margin using the ratio of net income before deflation to sales in year t as in Rao et al. (2004). High operation margin is expected to increase Tobin's $\mathrm{Q}$ because the high margin indicates greater cash flows in the future (Barth et al. 1998).

Growth Rate of Sales. We expect that high growth rate of sales has a positive impact on Tobin's Q (Barth et al. 1998: Rao et al. 2004). We use a moving average of growth rates of sales (i.e., growth rate in year $t=\left[\right.$ Sales $_{t} /$ Sales $\left._{t-1}\right]-1$ ) over the past three years as a measure of growth rate of sales.

Industry Concentration. We use Herfindahl index $(\mathrm{HHI})^{3)}$ to measure industry concentration level as in the prior literature (e.g., Mittal et al. 2005: Rao et al. 2004). High industry concentration indicates that a large amount of sales in an industry is from only a small number of firms in the industry. We anticipate that higher industry competition (measured by lower Herfindahl index) is associated with higher efficiency, and leads to higher Tobin's Q subsequently (Bharadwaj, Bharadwaj, and Konsynki 1999).

Table 1 presents descriptive statistics and correlation matrix of the variables. Analysts' forecast dispersion is negatively related to marketing intensity before controlling for other explanatory variables.

Figure 3 depicts the average of marketing intensity and analysts forecast dispersion across industries. Overall, the graph demonstrates a negative relationship between marketing intensity and analysts' forecast dispersion because industries with higher marketing intensity show lower level of dispersion (e.g., Retail and Food Product), while industries with lower marketing intensity show higher level of dispersion (e.g., Steel).

\section{Model Specification}

To empirically test the mediation role of analysts' forecast dispersion in the impact of marketing intensity on firm value, we adopt the three-step approach suggested by Baron and

3) Herfindahl Index $x_{j t}=\sum_{k=1}^{N_{j t}}\left\{\text { Sales }_{k t} / \sum_{m=1}^{N_{j t}} \text { Sales }_{m t}\right\}^{2}$, where $N_{j t}$ indicates the number of firms in industry in year t. In this study, we categorize with 25 industries as described in Figure 1. We also use alternative specifications of 4-digit and first 2-digit SIC codes and find that main results are not sensitive to specific industry classification 


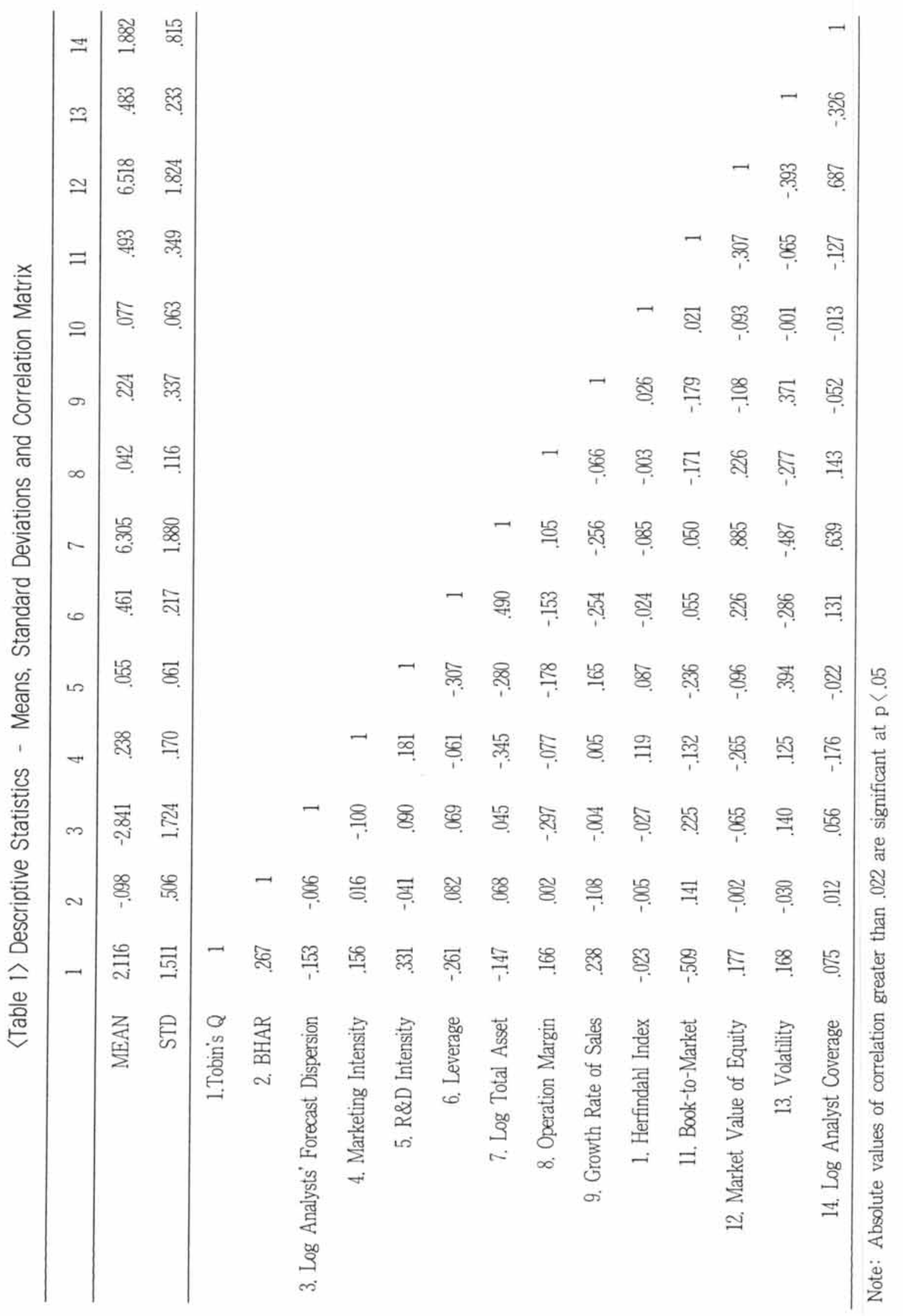

Informative Role of Marketing Activity in Financial Market: Evidence from Analysts' Forecast Dispersion 63 
〈Figure 3〉 Aggregate Mean Marketing Intensity and Analysts Dispersion Across Industries

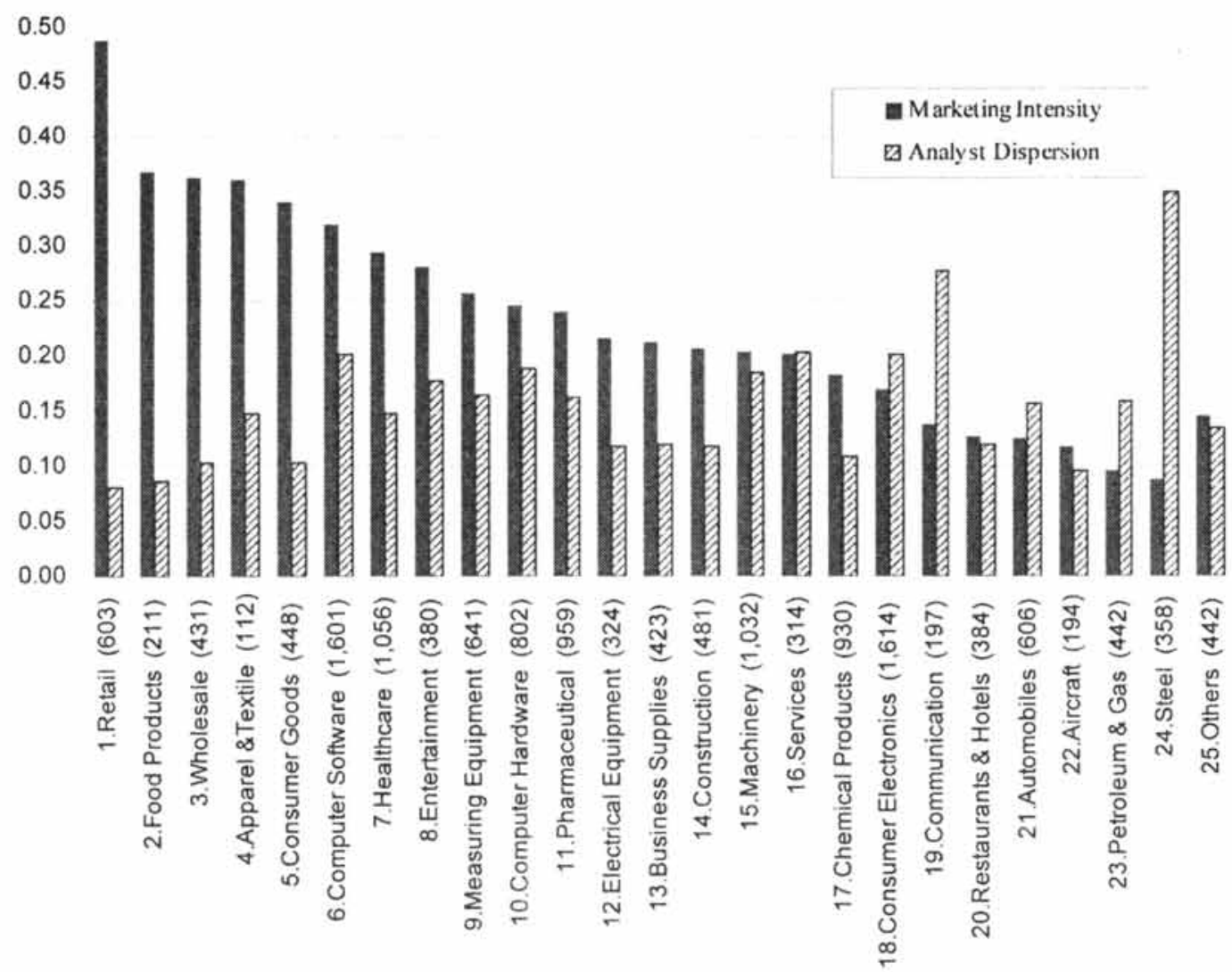

Notes: The number of firm-year observations within each industry is in parentheses.

Kenny (1986). In classic mediation approach, mediating variable (analysts' forecast dispersion) lies in the causal sequence between the independent variable (marketing) and dependent variables (Tobin's $\mathrm{Q}$ and BHAR). At first step, we formulate the baseline model as follows:

Tobin's $Q_{i t+1}=\beta_{00}+\beta_{02 m k t}+\beta_{03}$ ind $d_{i t}$ $+\beta_{04 l e v i t}+\beta_{050 m_{i t}}+\beta_{06} g_{i t}+\beta_{07 h h i t}$

$+\sum$ yearly fixed effects

+ Sindustry fixed effects $+\varepsilon_{1 i t+1}$

$$
\text { BHAR }_{i t+1}=\gamma_{00}+\gamma_{02} m k t_{i t}+\gamma_{03} m_{e i t}
$$

$+\gamma_{04} b t m_{i t}+\Sigma$ yearly fixed effects

+ Eindustry fixed effects $+\varepsilon_{\text {Qit }+1}$

where $m k t=$ marketing intensity, rnd $=$ R\&D intensity, lev $=$ leverage, om $=$ operation margin, $g T=$ growth rate of sales, hhi $=$ Herfindahl industry concentration index. $m e=$ market value of equity, $b t m=$ book to market, $v o l=$ volatility, and $\varepsilon_{\text {kit }+1}(k=1$, 2) is assumed to be i.i.d. normal distribution. If $\beta_{02}$ and $\gamma_{02}$ are significantly positive, that would indicate marketing activity directly increases firm value. Given that a panel dataset may introduce serial correlation and hetero- 
scedasticity, we use the Newey-West adjustment for standard errors (Newey and West 1987). In addition, we include year- and industry- fixed effects to control for unobserved heterogeneity.

To test $\mathrm{H}_{1}$, dispersion in analysts forecasts is regressed against marketing intensity in the second step as follows:

$$
\begin{aligned}
& \operatorname{disp}_{i t+1}=\delta_{0}+\delta_{1} m k t_{i t}+\delta_{2} r n d_{i t} \\
& +\delta_{3} \mathrm{vol}_{i t}+\delta_{4} \mathrm{lev}_{i t}+\delta_{5} \mathrm{ta}_{i t}+\delta_{6} \mathrm{acv}_{i t} \\
& +\Sigma \text { yearly fixed effects } \\
& + \text { }+ \text { industry fixed effects }+\varepsilon_{3 i t+1}
\end{aligned}
$$

where disp $=\log$ of dispersion in analysts forecasts, $v o l=$ volatility, $t a=\log$ of total asset, $\mathrm{acv}=\log$ of analyst coverage.

At the final step, we assess the channeling effect of analysts' forecast dispersion in the relationship chain where marketing activity has a direct effect on dispersion in analysts forecasts, which in turn causes changes in firm value. Thus, firm value (Tobin's $\mathrm{Q}$ or BHAR) is regressed against analyst dispersion and marketing as follows:

Tobin's $Q_{i t+1}=\beta_{10}+\beta_{11}$ disp $_{i t}+\beta_{12}$ mkt tit $+\beta_{13}$ Ind $_{i t}+\beta_{14}$ lev $_{i t}+\beta_{150 m_{i t}}+\beta_{16} \mathrm{gr}_{i t}$

$+\beta_{17} h$ hi $i_{i t}+\sum$ yearly fixed effects

+ Eindustry fixed effects $+\varepsilon_{\text {fit }}+1$

$$
\begin{aligned}
& \text { BHAR }_{i t+1}=\gamma_{10}+\gamma_{11} \text { disp }_{i t}+\gamma_{12} \mathrm{mkt}_{i t} \\
& \quad+\gamma_{13} \mathrm{me}_{i t}+\gamma_{14} \mathrm{btm_{it }}
\end{aligned}
$$

$+\Sigma$ yearly fixed effects

+ industry fixed effects $+\varepsilon_{5 i t+1}$

To test mediating role of information asymmetry $\left(\mathrm{H}_{2}\right)$, we assess whether the impact of marketing on firm value decreases after the dispersion variable (disp) is included.

Figure 1 shows a stylized mediation model applied in this study, where $c_{0}$ represents the direct effect of marketing on firm value without considering analysts forecast dispersion ( $\beta_{02}$ in Eq. (2), $\gamma_{02}$ in Eq. (3)), a represents the effect of marketing on analysts' forecast dispersion $\left(\delta_{1}\right.$ in Eq. (4)), $b$ represents the effect of analysts forecast dispersion on firm value adjusted for marketing ( $\beta_{11}$ in Eq. (5), $\gamma_{11}$ in Eq. (6)), and $c_{1}$ represents the direct effect of marketing on firm value adjusted for analysts' forecast dispersion ( $\beta_{12}$ in Eq. (5), $\gamma_{12}$ in Eq. (6)). Thus, the indirect effect (or mediated effect) of marketing on firm value through analysts' forecast dispersion is $a b\left(\delta_{1} \beta_{11}\right.$ Tobin's $Q, \delta_{1} \gamma_{11}-$ BHAR). Therefore the total effect of marketing on firm value equals to $c_{1}+a b\left(\beta_{12}+\delta_{1} \beta_{l 1}-\right.$ Tobin's Q. $\gamma_{12}+\delta_{1} \gamma_{11}$ - BHAR). Mediation by analysts' forecast dispersion is complete if $c_{0}$ and $a b$ are significant but $c_{1}$ is not, and it is partial if both $a b$ and $c_{1}$ are significant. A challenge in the classic mediation analysis is to test the statistical significance of $a b$ because the distribution of the product of two normally distributed coefficients is not normal and unknown. To overcome this 
limitation, we conduct a Bayesian version of mediation analysis (Zhang, Wedel, and Pieters 2009). We estimate all models using Markov chain Monte Carlo (MCMC) methods by recursively sampling from the full conditional distributions of parameters. We assume normal prior distributions for all regression coefficients and inverse gamma prior distributions for the variance parameters. MCMC estimation allows us to overcome the key limitation in the classic approach because the standard error of the indirect effect $(a b)$ and total effect $\left(c_{1}+a b\right)$ can be estimated by the draws from empirical sampling distribution.

\section{Results}

\subsection{The Impact of Marketing Intensity on Forecast Dispersion}

Table 2 shows that marketing intensity has a significant negative relationship $(-.906, \mathrm{p}<.01)$ with dispersion in analysts earnings forecasts. Therefore $\mathrm{H}_{1}$ is supported. This finding suggests that, all else being equal, higher marketing intensity is associated with lower information asymmetry. In addition, the signs of control variables are significant and consistent with our expectations. The positive coefficient of R\&D intensity reveals that firms with higher R\&D intensity have greater dispersion in analysts forecasts. It is interesting to note that marketing and $\mathrm{R} \& \mathrm{D}$ influence information asymmetry in the opposite direction. Prior marketing literature documents that both marketing and $R \& D$ have a positive effect on firm valuation (Rao et al. 2004). Yet, marketing decreases dispersion in analysts' forecasts while $R \& D$ increases the dispersion. This may suggest that firms want to reveal information through marketing activity by increasing awareness while they want to hide the details of innovations related $R \& D$ spending to protect their business ideas against competitors. Consistent with results in Thomas (2002), volatility plays an important role in explaining forecast dispersion $(t-s t a t=27.122)$. The coefficient of leverage is also significantly positive suggesting that firms with high leverage tend to experience high information asymmetry.

\subsection{The Effect of Marketing on Firm Value Mediated by Analysts' Forecast Dispersion}

In Table 2, results from the conventional threestep mediated regression approach (Baron and Kenny 1986) support the partial mediation role of analysts' forecast dispersion. After including the mediator variable about analyst dispersion, the effect of marketing intensity on firm value drops from $1.199(p<.01)$ to $1.130(p<.01)$ in Tobin's $Q$ model and the same effect drops from $.192(p<.01)$ to $.188(p<.01)$ in BHAR 


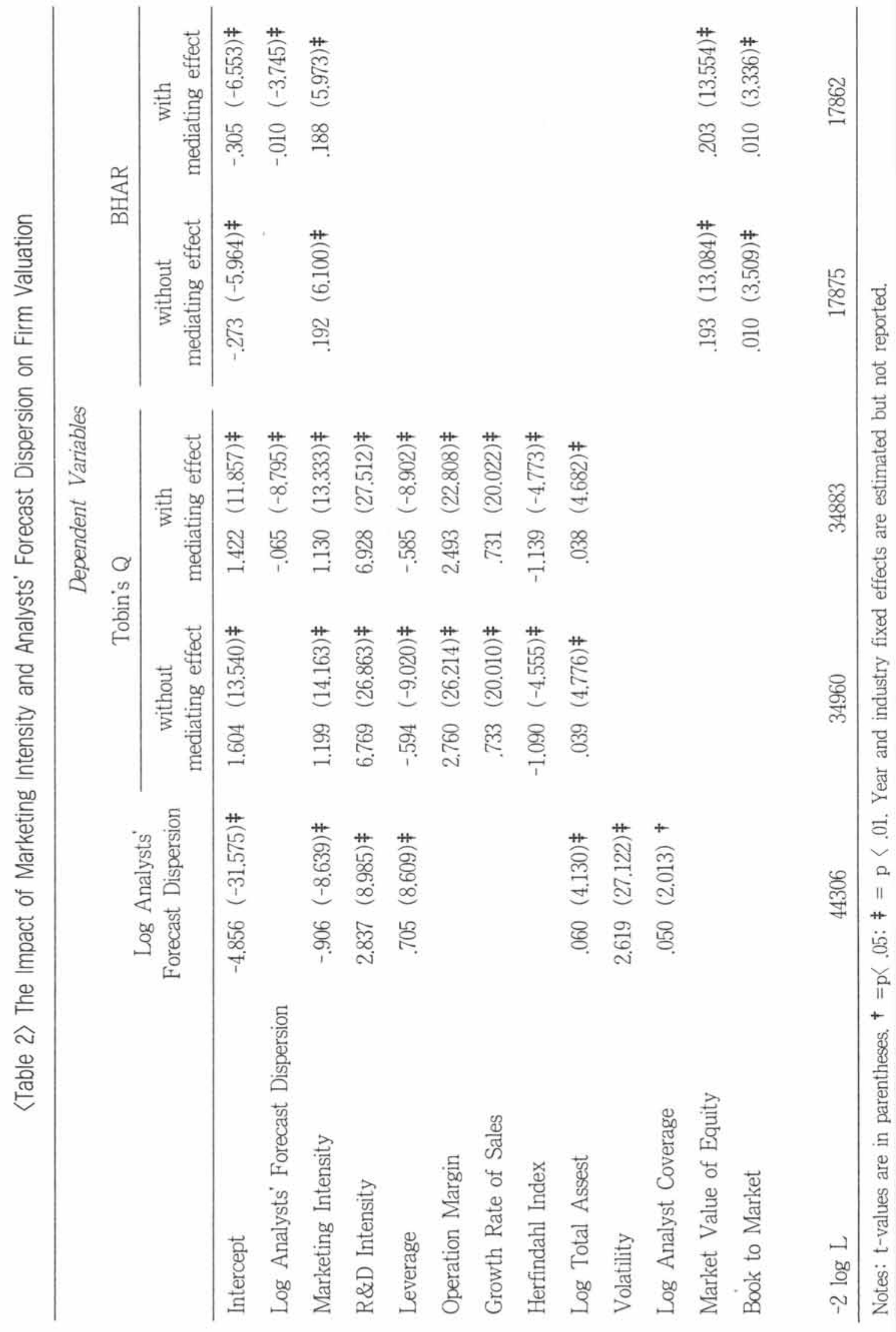

Informative Role of Marketing Activity in Financial Market: Evidence from Analysts' Forecast Dispersion 67 
model. Thus, $\mathrm{H}_{2}$ is supported; analysts' forecast dispersion partially accounts for the positive effect of marketing on firm valuation.

Table 3 reports results from the Bayesianbased mediation approach (Zhang. Wedel, and Pieters 2009). Since the Bayesian approach estimates standard errors more accurately, this approach is considered more robust to test mediation effects than non-Bayesian approaches. Therefore, we employ the Markov chain Monte Carlo (MCMC) methods with a Gibbs sampling algorithm and 5,000 draws for burn-in (Zhao et al. 2010: Luo, Wieseke, and Homburg
2012). The indirect effect (mediated effect) of analysts forecast dispersion $(a b)$ is $.058(p<$ $.01)$ in Tobin's Q model and $.009(p<.01)$ in BHAR, confirming the partial mediation role of analysts' dispersion. Thus, marketing has both direct and indirect impacts on firm value. Although the direct effect $\left(c_{1}\right)$ may contain some of indirect effect through boosting sales (Joshi and Hanssens 2010), the main focus of this study is to identify another indirect channel by reducing information asymmetry.

All control variables are significant and affirm our expectation based on prior literature

〈Table 3〉 Bayesian Mediation Results

\begin{tabular}{|c|c|c|c|c|}
\hline & \multicolumn{4}{|c|}{ Dependent Variables } \\
\hline & Log Analysts' Forecas & t Dispersion & Tobin's Q & BHAR \\
\hline Intercept & $-4.851 \neq$ & & $1.421 \neq$ & $-.306 \neq$ \\
\hline Log Analysts' Forecast Dispersion & & & $-.064 \neq b$ & $-.010 \neq b$ \\
\hline Marketing Intensity & $-.907 \neq a$ & & $1.135 \neq c_{1}$ & $.189 \neq c_{1}$ \\
\hline R\&D Intensity & $2.843 \neq$ & & $6.928 \neq$ & \\
\hline Leverage & $.709 \neq$ & & $-.595 \neq$ & \\
\hline Operation Margin & & & $2.532 \ddagger$ & \\
\hline Growth Rate of Sales & & & $.735 \neq$ & \\
\hline Herfindahl Index & & & $-1.137 \ddagger$ & \\
\hline Log Total Asset & $.060 \neq$ & & $.039 \neq$ & \\
\hline Volatility & $2.616 \neq$ & & & \\
\hline Log Analyst Coverage & $.050 \neq$ & & & \\
\hline Market Value of Equity & & & & $.010 \neq$ \\
\hline Book to Market & & & & $.205 \neq$ \\
\hline Indirect Effect of Marketing $(a b)$ & & & $.058 \neq$ & $.009 \neq$ \\
\hline Total Effect of Marketing $\left(c_{1}+a b\right)$ & & & $1.193 \neq$ & $.198 \neq$ \\
\hline
\end{tabular}

Notes: ${ }^{+}=\mathrm{p}<.05: \neq=\mathrm{p}<.01$. Posterior mean values are estimated on the basis of MCMC methods with a Gibbs sampling algorithm and 5,000 draws for burn-in. Year and industry fixed effects are estimated but not reported. 
(Rao et al. 2004: Smith and Watts 1992). That is, R\&D intensity, operation margin, and growth rate of sales are positively associated with Tobin's Q, while leverage and industry concentration measure (Herfindahl index) are negatively associated with Tobin's Q.

\subsection{Robustness check}

\section{Alternative Dependent Variable: Forecast} Accuracy. In our first hypothesis $\mathrm{H}_{1}$, we show that dispersion in analysts earnings forecasts decreases as a firm has higher marketing intensity. However, lower forecast dispersion does not necessarily imply better "accuracy" in earnings forecasts. If we believe that a firm's higher marketing activity provides additional information for investors to value the firm more accurately, it is also expected that higher marketing intensity leads to more accurate earnings forecasts. This leads to $\mathrm{H}_{1 \mathrm{a}}$ :

$H_{l a}$ (Forecast Accuracy): Analysts' earnings forecast errors decrease as a firm has higher marketing intensity.

The forecast error is measured as the absolute difference between mean forecasts and actual earning deflated by absolute value of mean forecasts. The coefficient for estimating the effect of marketing intensity on analysts forecast errors is negative and significant (= $-.263, \mathrm{p}<.01)$ in support of our hypothesis.
Further, forecast accuracy appears to partially mediate the role of marketing activity on firm valuation. With the mediating effect, the $\mathrm{co}^{-}$ efficient for estimating the effect of marketing intensity on firm valuation drop from 1.232 ( $\mathrm{p}<$ .01) to $1.115(\mathrm{p}<.01)$ in Tobin's $\mathrm{Q}$ model and the corresponding coefficient drops from .198(p $<.01)$ to $.174(\mathrm{p}<.01)$ in BHAR model (see Appendix I).

Alternative Marketing Metric: Advertising Intensity. We replace marketing intensity by advertising intensity (=advertising expense/ total asset) as an alternative marketing metric. Advertising intensity may serve as a better measure of marketing activity than marketing intensity because advertising expense is about pure marketing activity. However, the number of firms reporting advertising expense is much smaller than the number of firms reporting sales information on financial statements. For comparison purposes, we estimate the same regression models in the smaller sample where advertising expense information is available $(\mathrm{N}=4,666)$. The results based on advertising intensity are fairly consistent with our major findings based on marketing intensity (see Appendix II).

Changes in Marketing Expense. We also examine how changes in marketing expense affect analysts forecast dispersion and firm valuation. We expect that positive changes (or 
increase) in a firm's marketing expense will reduce dispersion in analysts earnings forecasts on the firm. The changes of marketing expense is measured by the differences of marketing expense(SG\&A-R\&D) from year $t-1$ to year $t$ scaled by marketing expense in year $t-1$. We confirm that the results based on the change measure of marketing expense are similar to the results based on the level measure of marketing expense. For example, the change measure of marketing expense has a significant negative effect on analysts' forecast dispersion $(=-.263, \mathrm{p}<.01)$. In addition, the mediating role of analysts' forecast dispersion in marketing and firm valuation is still supported with the change measure of marketing expense (see Appendix III).

\section{Conclusion}

This study examines marketing activity as a source of reducing information asymmetry in the financial market. Dispersion in analysts' earnings forecasts serves as a proxy for information asymmetry. Using a panel dataset of firm-year observations, we find that marketing intensity lowers analysts' forecast dispersion. Further, we find that reduced information asymmetry partially mediates the impact of marketing on firm valuation. Collectively, our results support the indirect impact of market- ing activity on firm value by providing additional information to professional investors. The findings have important implications for managers. First, managers should be cognizant of the role of marketing activity in providing information to the financial market as well as to the consumer market. Thus, managers should take into account investors' reaction when they design marketing communication messages for reducing the cost of capital. Second, this study shows a channel on how marketing creates shareholder value and highlights the accountability of marketing. In addition to the direct impact of marketing on firm value, an indirect channel by reducing information asymmetry should be considered. Potentially, marketing managers can justify their spending from the perspective of increasing long-term shareholder value.

Limitations. Our study solely depends on a quantitative measure- marketing expense- by assuming that it reflects the extent of marketing activity. However, the qualitative aspect of marketing may be more important to learn about how informative a marketing campaign is. For example, a firm's advertising campaign containing details on the firm and its products might diminish asymmetric information more effectively than an advertising campaign solely employing emotional appeals such as humor. Although marketing expense (SG\&A-R\&D) covers the costs related to important marketing activity (e.g., advertising, sales-force manage- 
ment cost, and promotional activity), we acknowledge that this measure may include "other expense" which is not directly related to marketing activity (e.g., legal cost). Yet, we do not expect any systematic effect of the other expense on information asymmetry and firm value, and thereby consider those extra portions as noise. Still, it would be desirable to use clean marketing metrics which can disentangle each portion. Then we are able to test which portion of marketing activity contributes most to reducing information asymmetry.

Future Research. Given that most companies use a mixture of various media (e.g., TV, radio, newspaper, and Internet) for communicating with final consumers, it would be interesting to examine which media vehicle is the most effective in reducing dispersion in analysts' earnings forecasts. Using the TNS media database that reports a firm's advertising spending across major media vehicles, we are able to test which media vehicle between the depth of information (e.g., the Internet and newspapers) and the breadth of information (e.g., TV and radio) helps investors better understand the valuation of the firm. Furthermore, our analysis could be extended to a firm's event on new product introduction because the probability of success on the new product is highly uncertain. Thus, we might expect that a firm's increased marketing activity will lower a measure of information asymmetry around the time of new product introduction and help investors more accurately evaluate the future prospect of the firm.

〈Received July 11. 2012〉

〈1st Revised July 10. 2013〉

〈2nd Revised August 26. 2013〉

$\langle$ Accepted September 3. 2013〉

\section{References}

Alford, Andrew W. and Philip G. Berger (1999), "A Simultaneous Equations Analysis of Forecast Accuracy Analyst Following, and Trading Volume," Journal of Accounting, Auditing, and Finance 14, 219-24.

Anderson, Eugene W., Claes Fornell, and Sanal K. Mazvancheryl (2004), "Customer Satisfaction and Shareholder Value," Journal of Marketing, 68(October), 172-85.

Atiase, Rowland K. (1985), "Predisclosure Information, Firm Capitalization, and Security Earnings Announcements," Journal of Accounting Research, 23, 21-36.

Baron, Reuben M. and David A. Kenny (1986), "The Moderator-Mediator Variable Distinction in Social Psychological Research: Conceptual, Strategic, and Statistical Considerations," Journal of Personality and Social Psychology, 51(6), 1173-82.

Barry, Christopher B. and Stephen J. Brown (1985), "Differential Information and Se- 
curity Market Equilibrium," Journal of Financial and Quantitative Analysis, 20, 407-22.

Barth, Mary E., Michael B. Clement, George Foster, and Ron Kasznik (1998), "Brand Values and Capital Market Valuation," Review of Accounting Studies, 3(1-2). 41-68.

Bharadwaj, Anandhi S., Sundar G. Bharadwaj, and Benn R. Konsynski (1999), "Information Technology Effects on Firm Performance as Measured by Tobin's q." Management Science, 45(July), 1008-24.

Chauvin, Keith W. and Mark Hirschey (1993), "Advertising, R\&D Expenditures, and the Market Value of the Firm," Financial Management, 22(Winter), 128-14.

Diether, Karl B., Christopher J. Malloy, and Anna Scherbina (2002), "Differences of Opinion and the Cross-Section of Stock Returns," Journal of Finance, 57, 2113-41. Erickson, Gary, and Robert Jacobson (1992), "Gaining Comparative Advantage Through Discretionary Expenditures: The Returns to R\&D and Advertising." Management Science, 38(9), 1264-79.

Fama, Eugene F. (1970), "Efficient Capital Markets: A Review of Theory and Empirical Work," Journal of Finance, 25(2), 383-417. Fang, Lily and Joel Peress (2009), "Media Coverage and the Cross-Section of Stock Returns," Journal of Finance, 64(5), 202352.
Fornell, Claes, Sunil Mithas, Forrest V. Morgeson III, and M.S. Krishnan (2006), "Customer Satisfaction and Stock Prices: High Returns, Low Risk," Journal of Marketing, 70 (January), 3-14.

Jacobson, Robert and Natalie Mizik (2009), "The Financial Markets and Customer Satisfaction: Re-examining Possible Financial Market Mispricing of Customer Satisfaction," Marketing Science, 28(5), 810-19.

Joshi, Amit and Dominique M. Hanssens (2010), "The Direct and Indirect Effects of $\mathrm{Ad}^{-}$ vertising Spending on Firm Value," Journal of Marketing, 74(January), 20-33.

Karamanou, Irene and Nikos Vafeas (2005). "The association between corporate boards, audit committees, and management earnings forecasts: An empirical analysis," Journal of Accounting Research, 43(2), 453-86.

Lang, M., and R. Lundholm (1996), "Corporate Disclosure Policy and Analyst Behavior," Accounting Review, 71(October), 467-92. Luo, Xueming (2008), "When Marketing Strategy First Meets Wall Street: Marketing Spendings and Firms' Initial Public Offerings," Journal of Marketing, 72 (September), 98109.

Luo, Xueming, Jan Wieseke, and Christian Homburg (2012), "Incentivizing CEOs to Build Customer-and Employee-Firm Relations for Higher Customer Satisfaction and Firm Value," Journal of the Academy of Marketing Science, 40(6), 745-58. 
Lyon, John, Brad Barber, and Chih-Ling Tsai (1999), "Improved Methods for Tests of Long-Run Abnormal Stock Returns," Journal of Finance, 54 (1), 165-201.

Merton, Robert C. (1987), "A Simple Model of Capital Market Equilibrium with Incomplete Information," Journal of Finance, 42(3), 483-510.

Milgrom, Paul and John Roberts (1986), "Relying on the Information of Interested Parties," Rand Journal of Economics, 17(1). 18-32.

Mittal, Vikas, Eugene W. Anderson, Akin Sayrak, and Pandu Tadikamalla (2005) "Dual Emphasis and the Long-Term Financial Impact of Customer Satisfaction," Marketing Science, 24 (4), 544-55.

Mizik, Natalie and Robert Jacobson (2003), "Trading Off Between Value Creation and Value Appropriation: The Financial Implications of Shifts in Strategic Emphasis," Journal of Marketing, 67 (January), 63-76. Mizik, Natalie and Robert Jacobson (2007). "Myopic Marketing Management: The Phenomenon and Its Long-term Impact on Firm Value," Marketing Science, 26 (3), 361-79.

Mizik, Natalie and Robert Jacobson (2008), "The Financial Value Impact of Perceptual Brand Attributes," Journal of Marketing Research, 45 (February), 15-32.

Mizik, Natalie and Robert Jacobson (2009), "Valuing Branded Business," Journal of
Marketing, 73 (November), 137-53.

Myers, Stewart C. and Nicholas S. Majuf (1984), "Corporate Financing and Investment Decisions When Firms Have Information That Investors Do Not Have," Journal of Financial Economics, 13(2), 187-221.

Nelson. Philip (1974), "Advertising as Information," Journal of Political Economy, 82 (4), 729- 54.

Newey, Whitney K., and Kenneth D. West (1987), “A Simple, Positive Semi-Definite, Heteroskedasticity and Autocorrelation Consistent Covariance Matrix," Econometrica, 55, 703-708.

Rao, Vithala, Manoj K. Agarwal, and Denise Dahlhoff (2004), "How Is Manifest Branding Strategy Related to the Intangible Value of a Corporation?" Journal of Marketing, 68 (4), 126-41.

Rust, Roland T., Tim Ambler, Gregory S. Carpenter, V. Kumar, and Rajendra K. Srivastava (2004), "Measuring Marketing Productivity: Current Knowledge and Future Directions," Journal of Marketing, 68 (October), 76-89.

Smith, Clifford W. Jr., and Ross L. Watts (1992), "The Investment Opportunity Set and Corporate Financing, Dividend, and Compensation Policies," Journal of Financial Economics, 3(December), 263-92.

Srinivasan, Shuba, and Dominique M. Hanssens (2009), "Marketing and Firm Value: Metrics, Methods, Findings, and Future Direc- 
tions," Journal of Marketing Research, 46 (June), 293-312.

Thomas, Shawn (2002), "Firm Diversification and Asymmetric Information: Evidence from Analysts' Forecast and Earning Announcements." Journal of Financial Economics, 64, 373-96.

Yi, Youjae, Kyoung Cheon Cha, and Cheonglim Lee(2008), "The Dynamic Effects of Cus- tomer Satisfaction on Firm's Profitability and Value," Asia Marketing Journal, 10 (1), 1-23.

Zhang, Jie, Michel Wedel, and Rik Pieters (2009), "Sales Effects of Attention to Feature Advertisements: A Bayesian Mediation Analysis" Journal of Marketing Research, 46 (5), 669-81. 


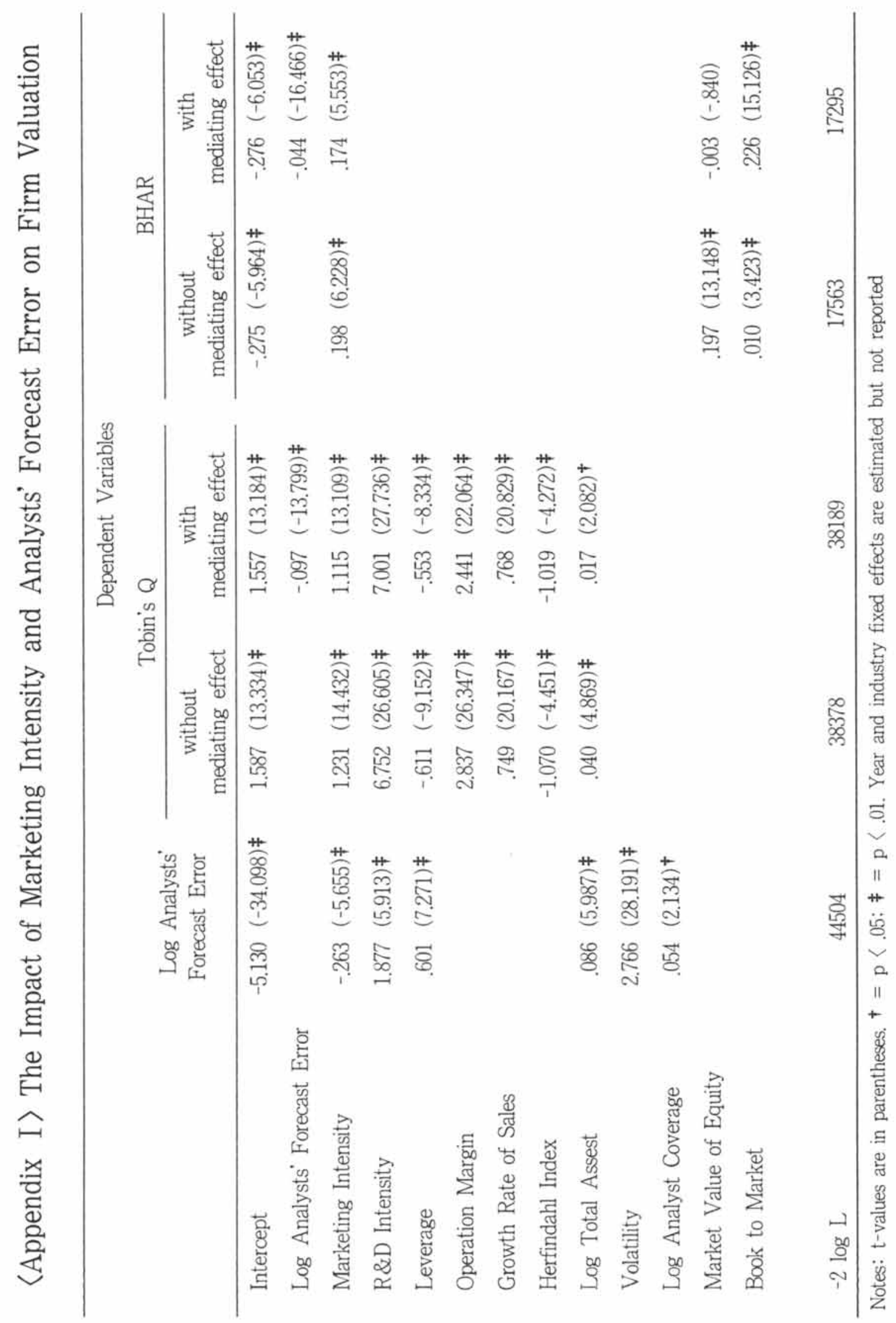

Informative Role of Marketing Activity in Financial Market: Evidence from Analysts' Forecast Dispersion 75 


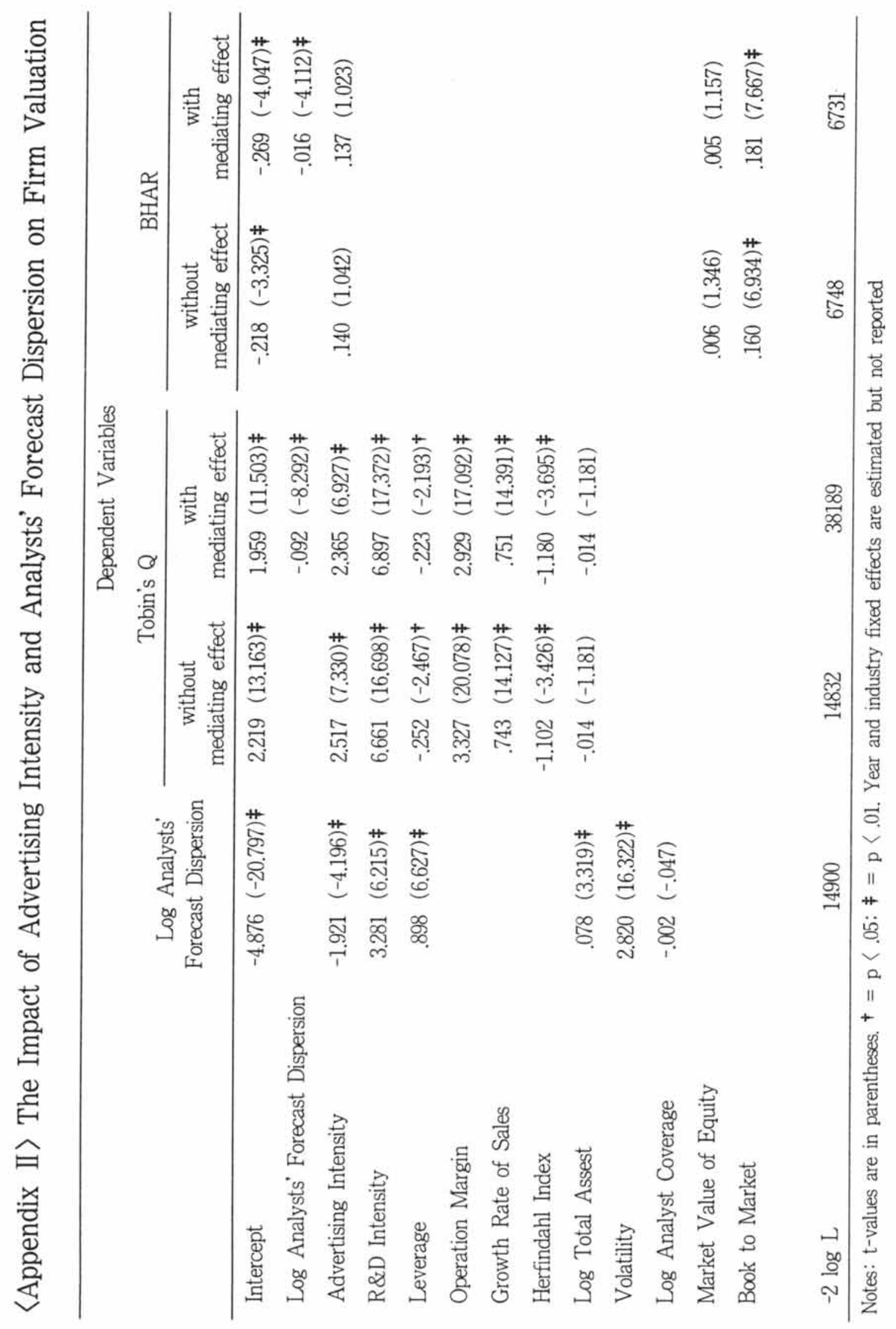




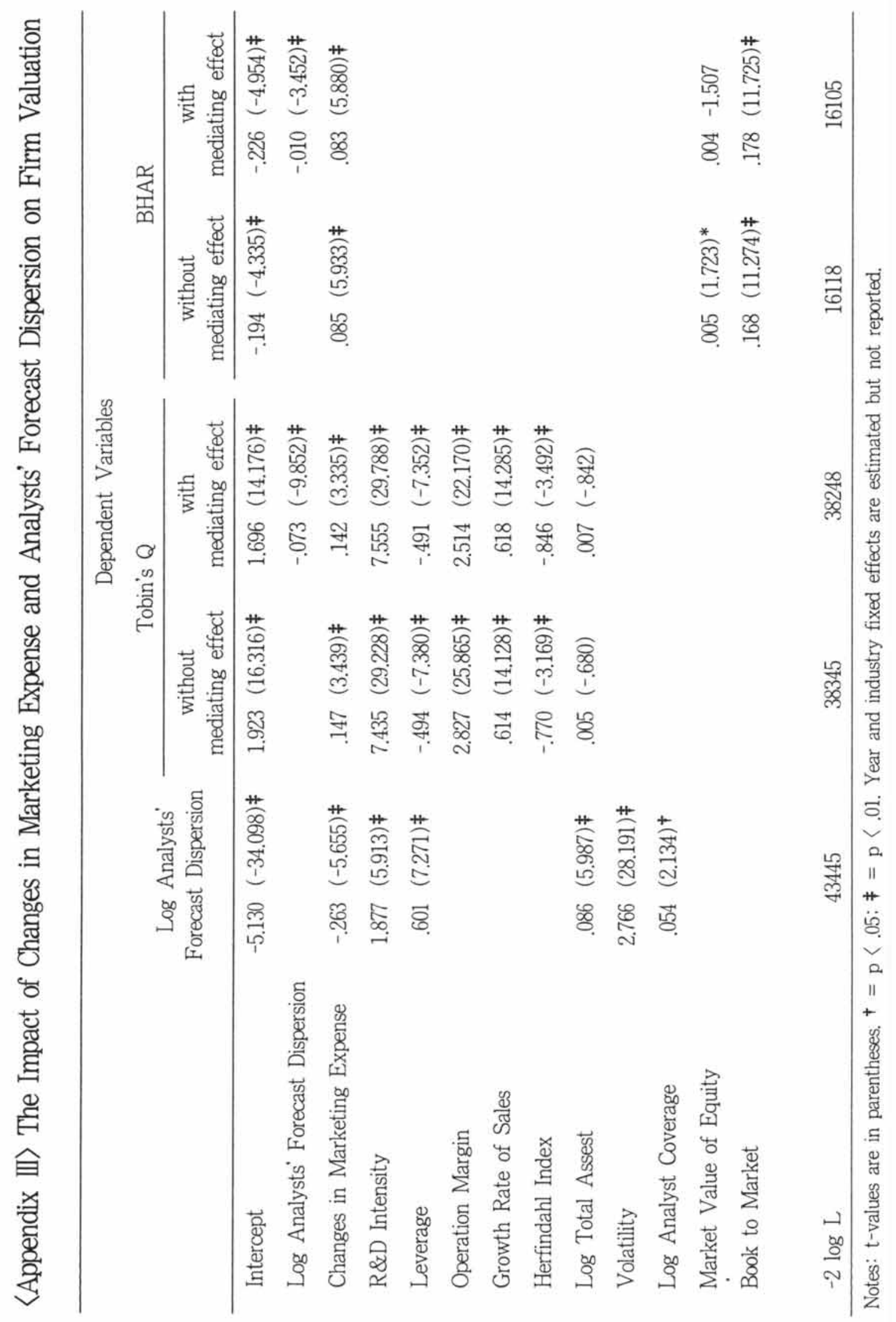

Informative Role of Marketing Activity in Financial Market: Evidence from Analysts' Forecast Dispersion 77 